\title{
Take me away ... In search of original dwelling
}

\author{
A.-Chr. Engels-Schwarzpaul \\ and Keri-Anne Wikitera
}

I. See Glossary for Māori and Samoan terms. Thanks to the anonymous reviewers and to Frances Edmond for her help in crafting the final text.
Take me away. ... Somewhere I can rediscover what is most important in my life (Sinalei Reef Resort \& Spa, n.d.-c).

The term "primitive" is increasingly ... a response to a mythic necessity to keep the idea of the primitive alive in the modern world and consciousness. And it will stay alive because there are several empires built on the necessity of the "primitive"... (MacCannell, 1990: 18).

An object which has always been lost cannot ... be remembered. The memory of which we speak, however, is ... of a state - of something that ... was done, was made: an action. It is a collective memory kept alive within groups by legends and rituals (Rykwert, 1981: 14).

When the morning sun bounces off the dew drops on teuila leaves, Sinalei Reef Resort \& Spa's natural and man-made beauty are striking. In this "careful blend of 'traditional and contemporary' architecture" (Sinalei Reef Resort \& Spa, n.d.b) orthogonal axes connect several buildings in the traditional Samoan style with modern ones.

Visitors approach the resort from the southern coastal road of Upolu, Samoa. Driving through its lush grounds, they eventually arrive at a palm tree-lined grass rondeau, which is divided into semi-circles by a central axis connecting the entrance with the ocean. Here, palm trunks merge into poles and palm fronds into roofs, as in the illustrations on pages 98-9 of Joseph Rykwert's book On Adam's House in Paradise. The entrance lobby looks like a fale tele, ${ }^{1}$ the round Samoan meeting house. The eyes wander down the long walkway leading to the beach, crossed by subsidiary axes that connect to a restaurant in a great, oblong fale afolau and, further down, to a bar in another fale tele. The layout at times seems to illustrate notions of the primitive entertained by Le Corbusier and Gottfried Semper. The former imagined primitive builders as guided "by instinct to the use of right angles, to axes, to the square and the circle", or by the "truths of geometry" which is "the language of the mind" (quoted in Rykwert 1981: 16). The latter saw "primitive man" taking "more pleasure in the regularities of the oarstroke and the handbeat ... than in the less differentiated one which nature offers him directly" (quoted in Rykwert 1982: 127). Le Corbusier and Semper were interested in the potential of architecture's origins, and shared with their contemporaries a view that modern life had been emptied of meaning and creativity. This perceived lack produced, then as now, a desire to experience authenticity, to escape to Paradise. The idea of the 'primitive hut' suggested renewal by returning to origins, serving as a leitmotif in the recreation of the existing (Rykwert 1981: 17). 




Sinalei Reef Resort \& Spa, site map. (C) Engels-Schwarzpaul 2009

Sinalei Reef Resort \& Spa, entrance area.

Photo: Engels-Schwarzpaul 2009

Today, Sinalei's slogan, "Take me away ...", plays on similar desires and conditions of lack. However, once made concrete, Paradise always seems to harbour the seeds of corruption: now as then, only a few can afford to enjoy paradisiacal beauty. Few have the means to stay at Sinalei as guests, and only some of those are Samoan. ${ }^{2}$ The flows of globalisation have always been unequal: over the last two centuries, not all who arrived in Samoa felt they arrived in Paradise. Many, for instance, had been "taken away" from their homes by colonial powers as indentured labourers. At the same time, in a reverse flow, people and houses were taken away from their communities of origin in Samoa and Aotearoa to glorify Empire in European and American exhibitions. Later, as people, finance, information, and objects became increasingly mobile, kit-set 'primitive huts' were produced in their countries of origin to be sent away as exhibits to the countries of former imperial powers, now 'global players'. This paper explores the circumstances under which some Māori whare and Samoan fale travelled overseas during the nineteenth and twentieth centuries - taken away to fill a perceived gap resulting from an erosion of meaning in the West. Today, the flow of houses from the Pacific to the "West" continues - while grand elaborations of Adam's House are built in Paradise for the few who can travel there.

\section{Taken away: original dwellings}

In the 1880s and 90s, with imperial modernisation reaching new heights, several Māori whare nui left Aotearoa/New Zealand to be exhibited, reassembled as curios, sold on, circulated or put into storage in museums. In 1893, as part of the routine display of exotic peoples at international exhibitions, Samoan fale were exhibited on the Midway of the World's Columbian Exposition in Chicago. Despite significant differences between Māori whare and Samoan fale, on many levels, they came to play similar roles in this scenario.

The story begins with Mataatua, whare tūpuna of Ngāti Awa, opened in 1875 as a "symbol of reconciliation between Ngāti Awa and other Iwi of the region" and the Crown (Wai 46, 1994). The Minister of Native Affairs, however, accused Ngāti Awa in the same year of "building Mataatua 'to raise an army"' (Sissons 1998: 42). In 1879, the Government requested Mataatua to be sent to the British Empire Exhibition in Sydney "as one of the finest examples of traditional Maori art" (39) - presumably to flaunt New Zealand's possessions to a rival colony. ${ }^{3}$ Despite internal opposition, Ngāti Awa leaders reluctantly agreed, perhaps to win favour with the government (Wai 46, 1994). However, they would hardly have anticipated the transformation awaiting the house at the exhibition: it was erected with the walls "reversed so that the carvings showed on the outside; and the total cost, including painting and roofing with Chinese matting was reduced
2. Sinalei's employees, who walk to work along beautiful beaches, are not likely to lead the idyllic life the resort's brochures suggest.

3. See Benedict (1991: 7). 
4. "Carved wall slabs and lattice work which had defined and given contemporary meaning to an interior space of inter-tribal debate and political dialogue were transformed into mysterious and passive surfaces, now readily available to the European gaze". (Sissons 1998: 44)

5. This fale was possibly the first 'kit-set fale' - purpose-built for an exhibition (unless the replica of Mata'afa's fale, below, is included in this category).

6. Hinemihi is referred to as a person as she represents an important ancestor of Ngāti Hinemihi and Tāhourangi.

7. See Gallop (1998: 33). to 165 pounds" (AJHR 1880, quoted in Smith, 1999: 53). Not only was the house's state of being changed - from "a 'living' meeting house, which the people used" to a "traditional curio" exhibited out of context and looked at by strangers (53) ${ }^{4}$ - but, after the exhibition, the New Zealand Government forwarded Mataatua, without consultation, first to Melbourne and then on to England. At the 1924 Wembley British Empire Exhibition, Mataatua was eventually displayed next to a Samoan fale from Mulinu'u. ${ }^{5}$ Next, Mataatua was expedited to the 1925 South Seas Exhibition in Dunedin, New Zealand, and then handed over to the Otago Museum. For decades, Ngāti Awa negotiated through various channels for its return as an ancestral house. "The house and our ancestors are standing in a 'foreign land' where they do not belong. It is time for them to come home." (Ngāti Awa Māori Trust Board quoted in Smith, 1999: 53) In 1996, the New Zealand government paid the museum " $\$ 2,750,000$ in return for acknowledgement of Te Rūnanga o Ngāti Awa ownership of Mataatua Whare" and its return home (Butt 2003: 98). Ngāti Awa's capacity to retain a committed relationship with Mataatua, to 'own' the house even while it was alienated, eventually also re-established legal and physical ownership, creating new potential for its community of origin (see Thomas 2009: 172).

Hinemihi o te Ao Tawhito's story is different, since she was conceived originally not only as a traditional meeting house for tribal gatherings, but also a venue to entertain visitors during the early days of New Zealand tourism. ${ }^{6}$ She was built by master carver Wero Taroi, assisted by Tene Waitere, at Te Wairoa in 1881, near Mount Tarawera and the famous Pink and White Terraces. Chief Aporo Te Wharekaniwha named her Hinemihi o te Ao Tawhito, or Hinemihi of the old world, emphasising the sense of a 'new world' emerging from the 'old'. ${ }^{7}$ Hinemihi's carvings represent significant ancestral genealogies. They also show signs of Western influence and changes in the economic environment: the ancestors wear bowler hats and Victorian shoes (Neich 1990-1991). After the 1886 volcanic eruption of Tarawera, Hinemihi was sold to Lord Onslow, then Governor General of New Zealand, who relocated her to his estate at Clandon Park in England in 1892. Today, Clandon Park is a tourist destination and Hinemihi thus continues her connection with the industry. Her physical presence, as a Māori whare, has not significantly changed over the past 127 years. What has changed since her relocation, though, is what she represents for the diasporic communities related to her. For those who connect to her through genealogy she is their whare tūpuna, while the members of Ngāti Rānana (the Māori expatriate community in London) have adopted her as their marae, the place where they congregate for the annual Kohanga Reo hangi, and where the children stage kapa haka and Pacific dance performances. Through those connections, her identity has remained intact in important ways, even when her function changed repeatedly: from a memento of Paradise to the Onslow family, to a boat shed, and storage room for outdoor furniture (Gallop 1998). While physically dislocated from her tribal origins, she has stayed present in tribal memory and kept alive by Ngāti Rānana. Thus, she is able to give rise to new ideas and concepts in current debates.

In Chicago, several Samoan fale were displayed at the 1893 World's Columbian Exposition - their names are not recorded. With many other buildings, their display contributed to a juxtaposition of buildings that made a visible comparison of the world, on a sliding scale between progress and underdevelopment. The Midway was the exhibition's amusement zone, and many of the nations exhibited there were perceived as "obsolete people", coming to the exposition "out of 
their mist" (Midway Types, "A Peep at Algiers" quoted in Armstrong 1992). The "Samoan Islanders" (only two of them Samoans) and their fale were located next to the South Sea Islands Village (Johnston 1999) and the Hagenbeck Animal Show (in Herdrich 2000). Harry Moors, an American-Samoan trader based in Apia, had shipped a fale and additional materials from Samoa (Johnston 1999: 108). The 'villagers' re/constructed the building/s on site, thus giving "an atmosphere of authenticity to the village" (111). ${ }^{8}$ During the exhibition they could be seen, like other groups of exotic peoples, "living and performing against backgrounds like those at home" (Furnas 1948). Moors probably also created a well-tended myth to enhance the exhibits' attraction: the largest fale had supposedly "belonged to King Mata'afa, the deposed ruler of Samoa, who occupied it for years". ${ }^{9}$ Whether or not it belonged to Mata'afa, the "subliming of the exotic and oriental" had, by that time, become a "requisite of the commercialization and commodification of exotic others" (Armstrong 1992: 200). ${ }^{10}$ In contrast to Mataatua and Hinemihi, the fale's fate following the Chicago exhibition seems unknown, and no connection with Samoan communities seems to exist.

\section{Sent away: kit-set authenticity}

Before the middle of the twentieth century, indigenous houses were usually taken away without much consultation with, let alone involvement from, their original communities. From the 1960s, alongside continuing globalisation and beginning decolonisation, tourism and leisure industries expanded to an unprecedented extent. Simultaneously, rationalisation and "disenchantment of the world" (Weber 1917) continued in Western societies. While exhibitions of 'traditional' dwellings in modern edutainment contexts perpetuated the display of exotic others, the buildings were often no longer built for community purposes but pre-fabricated in their countries of origin to be sent away for display overseas. The 'natives', as it were, now colluded with Western interests, motivated by an ongoing quest for origins in modernised countries. The two instances of theme park exhibitions discussed here were both conceived by entrepreneurs who were not only outsiders to the houses' communities of origin, but also to the environments in which they set up native or tropical villages. Both appeal to a yearning for authenticity and Paradise. ${ }^{11}$

Since 1963, several fale and whare have been on display at the Church of Latter Day Saints' Polynesian Cultural Center (PCC) in Lā'ie, Hawai'i. The seven "native villages" were conceived in 1951 by Matthew Cowley, a missionary in New Zealand during the 1920s, who anticipated "the day when my Māori people down there in New Zealand will have a little village ... at Lā'ie with a beautiful carved house ... the Tongans will have a village too, and the ... Samoans and all those islanders of the sea" (Polynesian Cultural Center, n.d.-b). Cowley, who assumed that Polynesian cultures and traditions would "endure if they were shared with others" (Polynesian Cultural Center, n.d.-b), ${ }^{12}$ had probably been a driving force behind the Church's funding for Kahungunu, a carved meeting house in Nuhaka, New Zealand, honouring Māori returned WW2 soldiers. PCC plans to ship Kahungunu to Lā'ie in the 1960s, to form the nucleus of a Māori village, met with an uproar in Nuhaka, and it was decided to commission a new whare instead (Skinner 2008). Te Aroha o te Iwi Māori was produced by carvers and weavers in New Zealand, then shipped to PCC to be assembled on site. ${ }^{13}$ Thus, Māori (and possibly Samoans) were to some extent involved in the decision-making about aesthetics and performance of their buildings from the beginning. ${ }^{14}$
8. While the impression was created that the villagers were Samoans, probably only two women were from Samoa: the '“'Mulunu'u Government' had opposed the enterprise and ... refused to allow any Samoans to accompany [Harry Moors] to the United States" (Johnston, 1999: III, II2).

9. A myth promulgated by Prof. Culin, in his report on the exhibition, and by Frank Smith (1893: n63). More likely, the fale was a replica since "during the exhibition, the original fale tele was destroyed when Mata'afa was forced to burn his entire village following his defeat" (Johnston 1999: I13).

10. While undoubtedly belonging to those artefacts at the exposition which, by signalling 'underdevelopment', provided the contrast needed to make the White City stand out, the Samoan fale were nevertheless admired for their ability to keep out the heat in a smouldering Chicagoan summer (Johnston 1999: |14).

II. See (Polynesian Cultural Center n.d.-c) and (Tropical Island Management $\mathrm{GmbH}, 2008$ ).

12. See Webb (1998: 35).

13. According to the website, Te Aroha o te Iwi Māori was the first whare nui ever built outside of New Zealand.

14. See Polynesian Cultural Center (n.d.-a). 


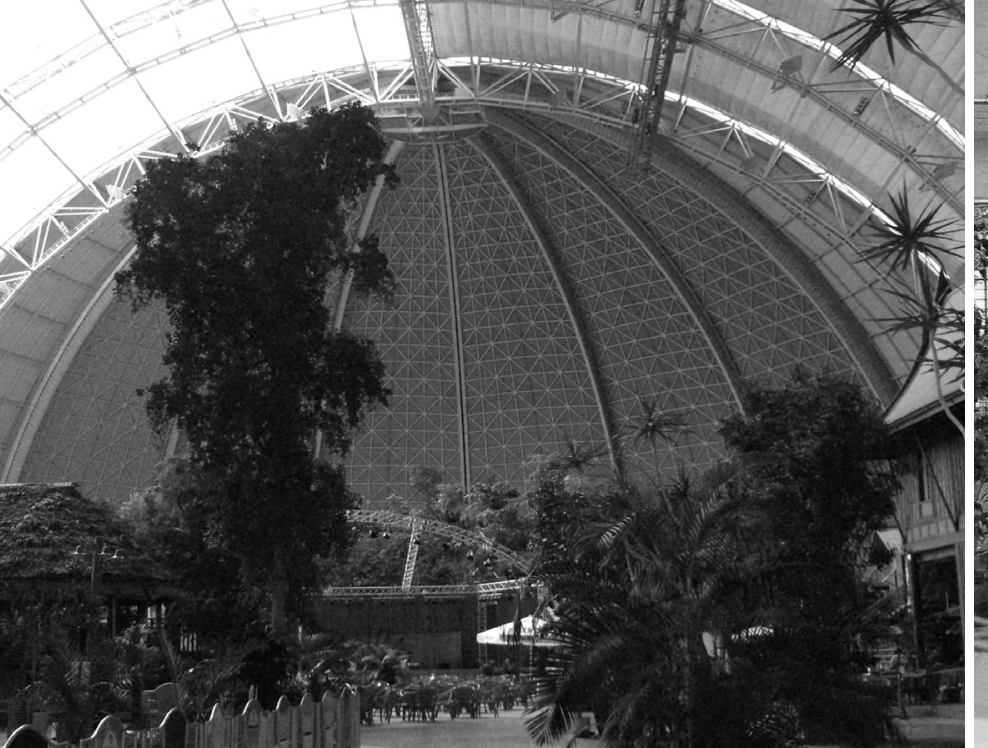

Tropical Islands Resort, dome exterior. Photo: Engels-Schwarzpaul 2007

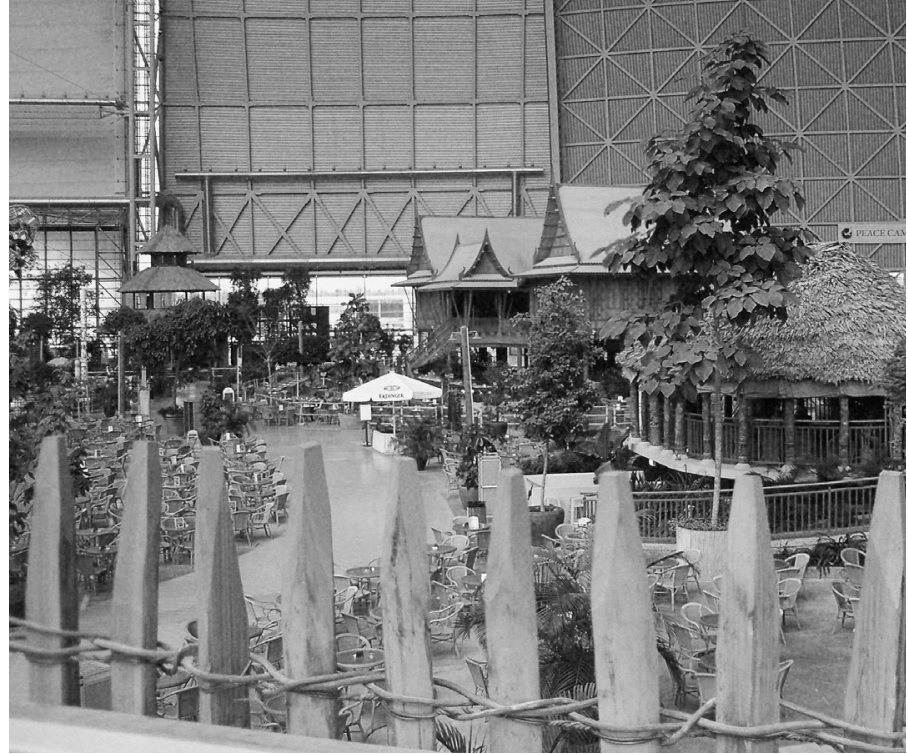

Tropical Village at Tropical Islands Resort. Photo: Engels-Schwarzpaul 2007
I5. See Engels-Schwarzpaul (2007)

16. Samoa was a German protectorate from 1900 to 1914 .

17. Contractual relationships were fraught and, today, relationships appear to have lapsed.
At PCC, marketed as a "living museum" for several Pacific cultures, Church College of Hawai'i (now Brigham Young University) students entertain tourists with Polynesian songs and dances to pay for their education (Stillman 2004; Webb 1998).

A recent instance of a fale's exhibition in a foreign context occurred in 2005 at the Tropical Islands Resort at Brand, $60 \mathrm{~km}$ southeast of Berlin. Colin Au, a Malaysian multi-millionaire, wanted to bring the tropics to Germany. He set up a resort in the dome of a gigantic disused hangar, where "rainforest flora and fauna and six [houses represent] indigenous cultures" (dpa, 2004). ${ }^{15}$ Au assembled what he considered the best specimens to convey a sense of authentic tropics: all houses were produced in their countries of origin, specifically for the resort. Thus, he went to Apia and commissioned the Samoan Tourism Authority to deliver a fale matching an image he brought with him, constructed by local tufuga fai-fale using local traditional materials. Months later, the fale's components were shipped to Germany and erected by the tufuga in the resort's Tropical Village. ${ }^{16}$ In 2005, a Samoan troupe came to perform The Call of the South Sea to a German and international public in the vicinity of their fale. Samoans were not asked for their advice when $\mathrm{Au}$ chose the fale he wanted built and, while they had a certain amount of control over its construction, they have no say in its ongoing use. ${ }^{17}$ The fale's presentation on the website bears only a tenuous relation with reality: it is described as a "typical Polynesian straw hut", "a sort of 'community house' for several villages", with " 28 beautifully carved wooden posts [representing] one of the participating extended families" (Tropical Island Management GmbH, 2005). While its initial display at the resort at least indicated a sense of taste and quality, by November 2008 it was a cocktail bar and smokers' lounge littered with cigarette butts, empty glasses and bottles.

\section{In the heart of the Pacific}

... Samoa in the South Pacific. So many have called it Paradise but we call it Home. Our staff walks to work along the beach from the villages nearby. ... (Sinalei Reef Resort \& Spa, n.d.-b).

On the other side of the world, in the heart of the Pacific, Sinalei Reef Resort was built "to the desired concept of its Samoan owners" and opened in February 1996 (Sinalei Reef Resort \& Spa, n.d.-a). "Set in 3 acres of lush tropical garden on the south coast of Upolu", its blend of traditional and contemporary architecture fits square utilitarian buildings with corrugated iron roofs between straight axes and traditional round buildings. 

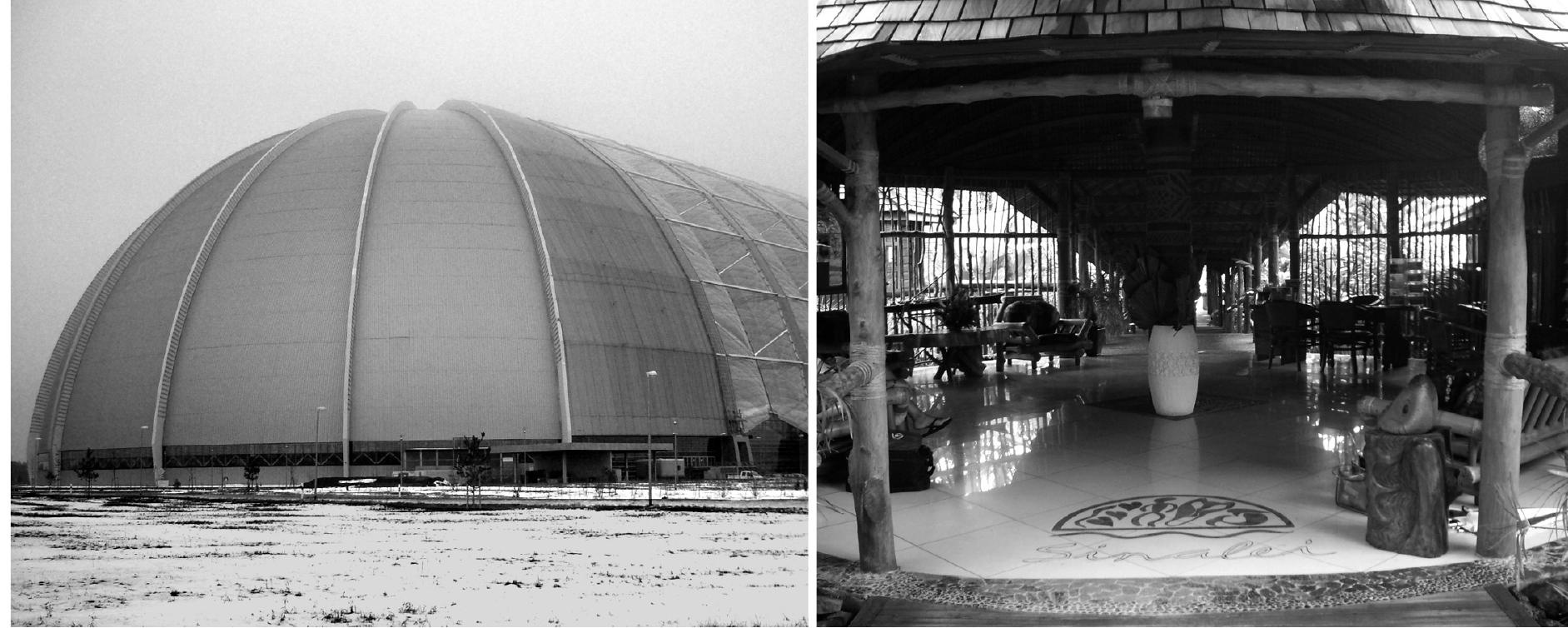

Tropical Islands Resort, dome interior.

Photo: Engels-Schwarzpaul 2007

Sinalei Reef Resort E Spa, entrance area with stump.

Photo: Engels-Schwarzpaul 2009

For anyone unfamiliar with Samoan architecture and social context, the traditional buildings appear authentic. ${ }^{18}$ Raised floors, layouts and roof shapes, the materiality and intricacy of lashed timber joinery and weaving - these are iconic elements, not only of Samoan architecture but also of the notion of the primitive hut (Rykwert 1982: 124). Remarkably, though, one enters both fale tele (entrance lobby and bar) through the tala, the curved part of the roof, where the highest ranking participants in a fono would sit in the village context. In the entrance fale, the tala's middle post (marking the most important place) is cut off - the remaining stump perhaps indicating a significant absence to the initiated. I asked a tufuga fai-fale about this irregularity in 2008, the tufuga laughed and commented that this fale had nothing to do with fa'a Samoa. While Refiti (2008) holds that the Samoan architectural motivation does not stem from a fascination with a "return to origins" or a "renewal of human activity" (Rykwert 1981: 192), Samoan resort architecture does play on this fascination. At Sinalei, it meets the Western imagination of a return to origins when traditional dwellings are imbued with a potential to help visitors "rediscover what is most important" in their lives.

Visitors can book a paid walk with a staff member and "share the local village" or "sample what village life has to offer" (Sinalei Reef Resort \& Spa, 2008). In Dean MacCannell's terms, this expedition involves staged authenticity, the "pretentious revelation of back region 'secrets'" which belongs to a realm between front-of-stage and backstage. ${ }^{19}$ It creates a sense that one "'got in with the natives' or experienced local life as the natives experience it" (MacCannell 2008: 336). In Sinalei's brochure, village life stands for a home in paradise,$^{20}$ which the visitor is implicitly invited to share. Some aspects of this invitation are more obviously performative than others: dancers, waiters and bartenders at Sinalei act clearly front-of-stage in MacCannell's terms, while cooks and cleaners act backstage. Clearly not all is revealed - and what is revealed tends towards the "performative primitive". To "act-primitive-for-others" is an adaptive strategy of non-modern peoples to modern existence, in which they "combine modern elements of self interested rational planning and economic calculation with primitive costumes, weapons, music, ritual objects and practices that once existed beyond the reach of economic rationality" (1992: 19)

Visitors at Sinalei are likely to register the performances staged for them in the front regions - the open and round spaces of fale afolau and fale tele. Around and between them, service and private areas (kitchens, offices, conferences, toilets, accommodation) are housed in unstaged back regions - square and closed-off buildings.
18. That is, corresponding to images and descriptions in, for instance, Buck (1949) or Krämer (1994).

19. MacCannell inserted this realm "between [Goffman's] front-back binary to name a new kind of space that could not be assimilated into either one of the original pair" (2008: 335).

20. "You'll call it Paradise, we call it home" is an established slogan of the $\mathrm{Pa}$ cific tourism industries, beyond Samoa. 


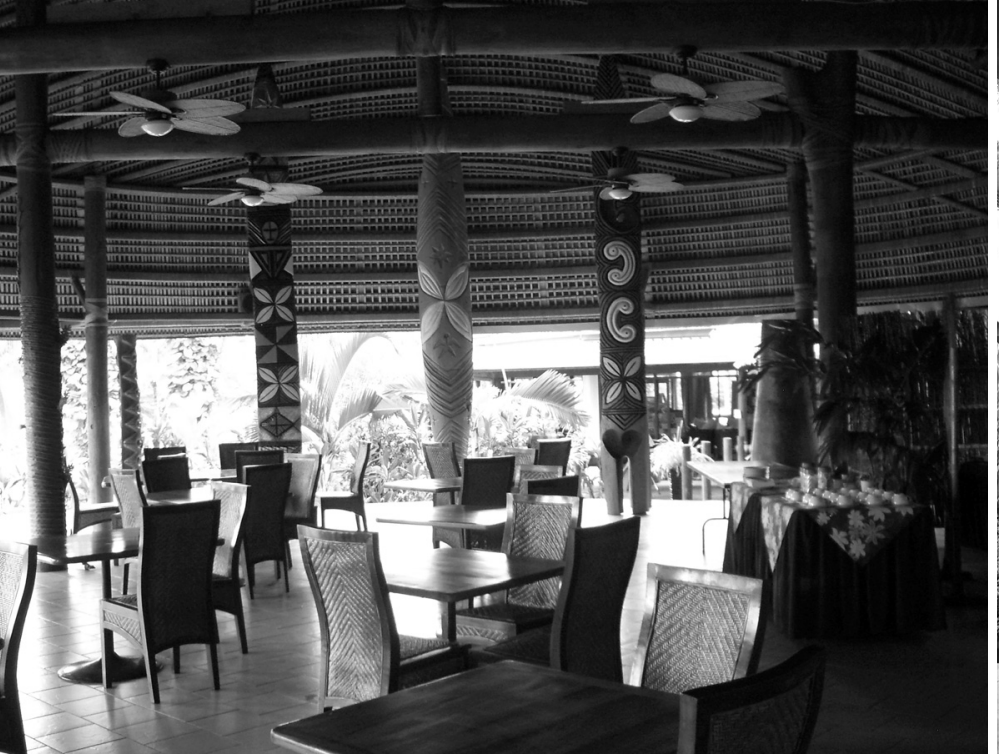

Sinalei Reef Resort E Spa, dining area in Fale Afolau. Photo: Engels-Schwarzpaul 2009

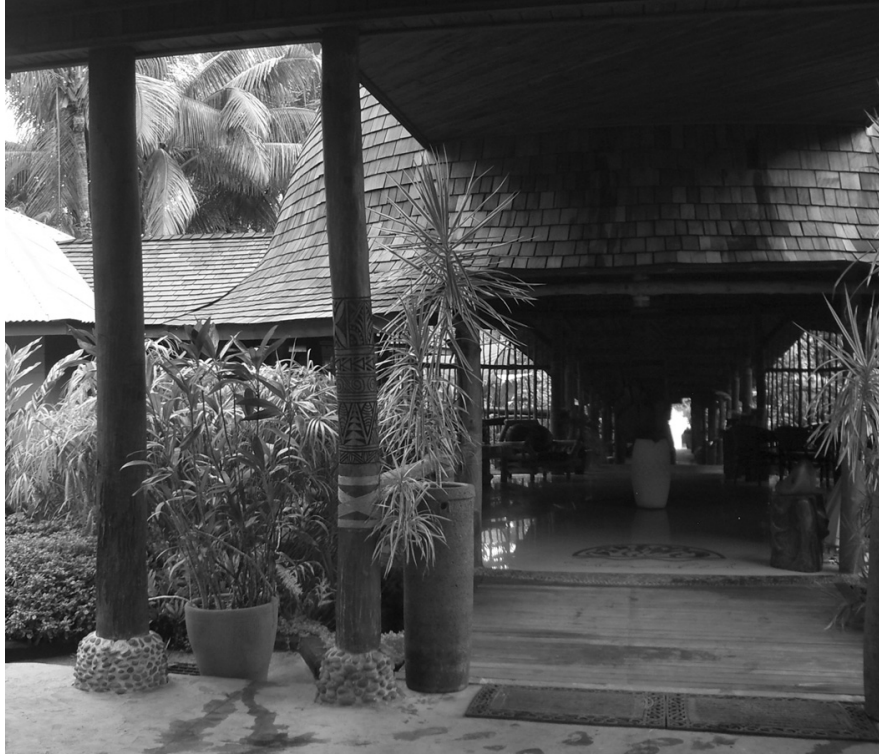

Sinalei Reef Resort \& Spa, central walkway.

Photo: Engels-Schwarzpaul 2009
21. Sinalei's covered walkways stream movements, not unlike the way in which flows are channelled in airports - a feature not found in villages.

22. The embodiment of cosmological order at various levels in Polynesian culture, e.g. in the fale, was frequently observed by outsiders in the past (e.g., Finley \& Churchill 1923: 114) and is elaborated today by Tui Atua (2008).

23. In On Adam's House in Paradise, he speculates on the Jewish huppah, a suspended canopy under which marriage vows are taken. Rather than keeping the weather out, it provides the couple with "a mediation between the intimate sensation of their own bodies and the sense of the great unexplored world around", "a model of the world's meaning" (190). Preziosi (1982: 320) detects a strange lapse in Rykwert's conclusion, given that most of the book is devoted to demonstrating architectural theories' implication in myths of origins. Rykwert seems to fall victim to his own myth of origins when the description of the huppah's primary function, to provide an image of its occupants' bodies and a "model of the world's meaning", leads him to "postulate a house for Adam in Paradise" (Rykwert 198I: 190).

24. Austin remarks that Rykert's 'primitive hut' appears fixed in place and proto-classical (2004: 229) whereas, in some Pacific myths of origin (though not in Samoa), houses might have originated from sea craft and roofs resemble naval vessels (225-6; Tcherkézoff 2008: 282). Semper's Caraib Hut (reproduced but not discussed in Adam's House in Paradise) is mostly open, and thus related to the fale Samoa and other Pacific house types. However, most other illustrations of the primitive hut in Adam's House in Paradise tend towards wall enclosure (e.g., pp. 39, 70, 72; 106, 138, 174).
Linear spaces of movement - axes at the resort, or the beach between resort and village - provide a transitional realm: between staged authenticity as "a quasifictional locus of fantasies of fulfilment" (MacCannell 2008: 337) and an authenticity which does not bear staging (toil, poverty and private secrets). In relation to the resort, life in the village is placed backstage - and the walk through the village promises a glimpse into "local life" in Paradise. But, if the village is a back region to the resort, it is itself also constituted of front and back regions: traditionally, fale tele border onto the malae in the front, with the family's other fale clustering behind. The enclosure of back regions, so typical of Western building traditions and increasingly common in Samoa since the 1970s, adds a further layer to this series. ${ }^{21}$

\section{In search of original dwelling: relationships, identity and place}

[The primitive hut] will continue to offer a pattern to anyone concerned with building, ... situated permanently perhaps beyond the reach of the historian or archaeologist, in some place I must call Paradise. And Paradise is a promise as well as a memory" (Rykwert 1981: 192).

There is an affinity between the fale Samoa - typically open, allowing air movement without restriction - and Gottfried Semper's notion of a house built by man in a world of wonders and unknown forces, as a "small world of his own, in which the cosmic law acts in a small, but independent system" (Semper 1878: XXI). ${ }^{22}$ While, until the eighteenth century, the primitive huts of architectural speculation "were always situated in an idealized past" (Rykwert 1981: 190), Semper writes during a time which increasingly located them in an anthropological present. Idealised past and anthropological present allow for a perception of a universal "drive in man's creative activities: that of echoing the essential rhythm of nature as the spur to the acquisition of skills" (191). A century later, Rykwert postulates "a house for Adam in Paradise", an assimilation of his body to the world, which establishes him "at the center" of the "paradisical plan" (190). ${ }^{23}$

Donald Preziosi sees a "strong centripetalism of an inescapable metaphorical machine" at work here, one that projects a cosmology organized around the centre of a labyrinth "in which one is already prisoner". Thus, "even in the midst of a purportedly demystifying discourse, metaphorical knots and ideological double binds ... may yet retain an inescapable power" (Preziosi 1982: 321). Metaphors can stimulate interest and understanding, or turn into clichés. To an extent, this happened to Rykwert when he assumed the primitive hut to be stationary and earthbound, while buildings in the Pacific have a closer connection to the sea. ${ }^{24}$ 


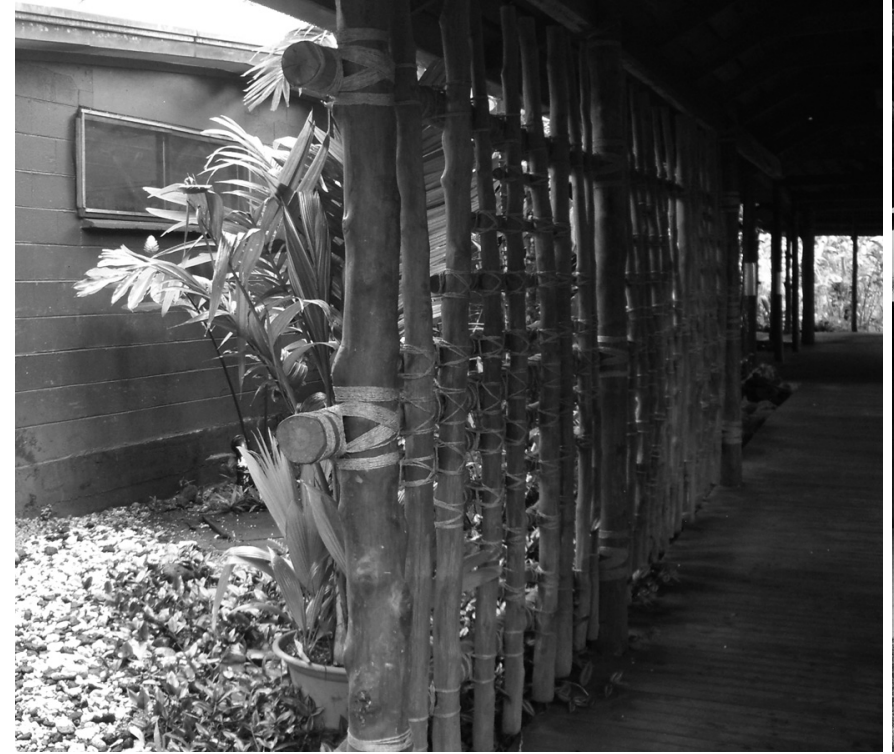

Sinalei Reef Resort \& Spa, subsidiary walkway. Photo: Engels-Schwarzpaul 2009

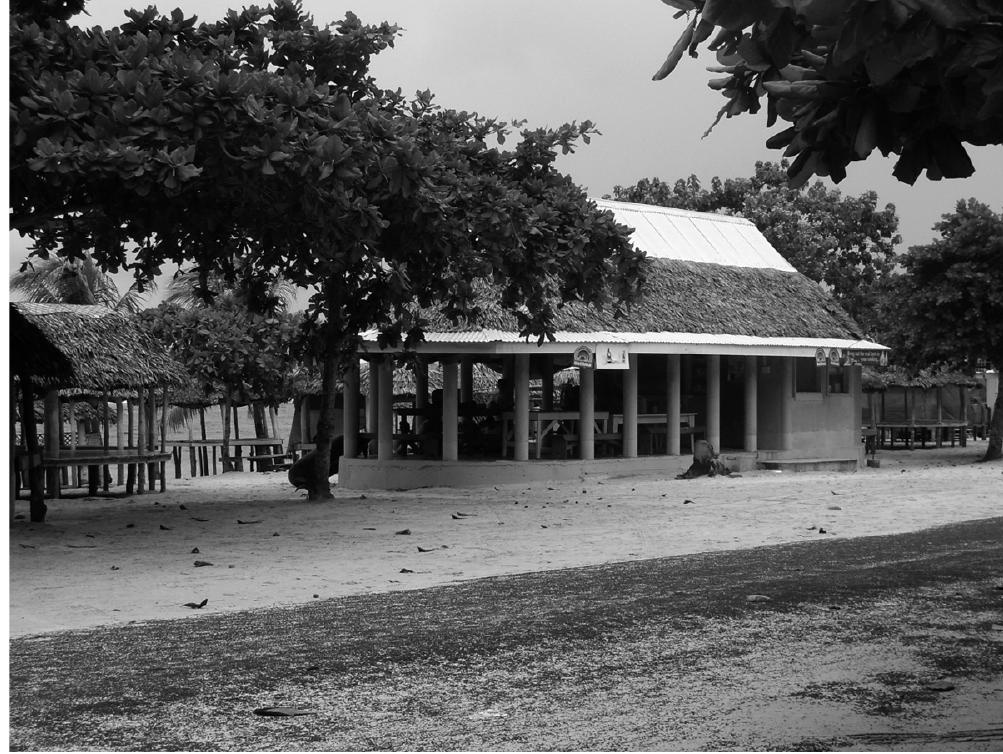

Fale at Lalomanu Beach resort, Upolo, Samoa.

Photo: Engels-Schwarzpaul 2009
A longing for a common origin within all given diversity may have ordered the unknown in the form of the known and blinded Rykwert, and the generation of architectural theorists that followed him, to alternative readings.

This blindness may even be related to a blindness caused by the desire for "profit without exploitation", which can be so strong that "even intellectuals can trick themselves into finding it where it does not exist ... The touristic ideal of the 'primitive' is that of a magical resource that can be used without actually possessing or diminishing it" (MacCannell 2008: 320). Thus, the paradise Samoans call home, although certainly not Paradise before the Fall, is portrayed by natives and visitors alike as a inexhaustible resource. ${ }^{25}$ It remains the forever displaced locus of a desire that cannot be sated (neither in psychoanalytic, nor in aesthetic, economic or political terms). One of the problems of the Samoan fale at Tropical Islands Resort might therefore be its ordinary closeness, which collapses desire for authentic origin. ${ }^{26}$ Authenticity, in the West, has posed a problem ever since modernity's differentiation produced, inter alia, the division of social "front" and "back" areas, and with it a weakened sense of reality. ${ }^{27}$ "Great blunders", wrote Heinrich von Kleist in 1810, are unavoidable once the door to Paradise is locked and bolted, and the only way to Paradise may be to "journey around the world, to see if a back door has perhaps been left open" (1982: 216).

Multidirectional journeys have already taken place and more may be required. Mataatua, taken away from Whakatane in 1879, travelled to Australia and England and back to New Zealand as an ethnographic artefact and national icon of sorts, finally returning home to Whakatane as a tāonga and core of a future tribal cultural centre. As for Hinemihi, the National Trust now work with Māori to ensure that future development represents the whare's cultural and conservational authenticity. ${ }^{28}$ In this, contemporary Māori's capacity "to identify with, celebrate, and reclaim tāonga fosters not despair but a sense of hope" (Thomas 2009: 172) and the development of new perspectives. On the other hand, ongoing collaboration of institutions with the communities of origin promotes an understanding that looking after tāonga includes actively maintaining relationships with their spiritual owners. "'Keeping the tāonga warm', from a Māori point of view, means re-establishing links with Māori people where they have been broken, and by so doing, helping to conserve the essence ... of the tāonga themselves" (Terrell, Wisse, \& Philipp 2007: 96). ${ }^{29}$ Changes of structure, location, ownership and usage have not stopped Hinemihi from embodying her original cultural and spiritual reference points, which now have relevance to Māori in England, her people at home in Aotearoa/New Zealand and Māori visiting England. Originally linking people through whakapapa, she has become a focus through which
25. Similarly, Adam's House in Paradise, aka the Primitive Hut, may still serve as a lost origin for modern and postmodern architects, a locus where their very own superfluidity might suggest a healing of wounds caused by the partially factual, partially perceived disenchantment in Western societies. Le Tagaloa Pita, former Minister of Tourism and Member of Parliament, suggested in a 2009 interview that an environment in which hunger and cold are never lifethreatening is conducive to a practical philosophy centred on love, rather than self-interest (Engels-Schwarzpaul \& Refiti, 2006-2009).

26. The production of familiarity in the exotic has a long tradition in German organised encounters with the strange, but these encounters always included people with whom a co-production of iconicity was at least in principle possible (see Ames 2004). One consistent difference between the whare and fale discussed here is that the whare are embedded in contemporary Māori social relationships, to varying degrees, whereas the fale seem more like commodities for their owners to sell.

27. By a strange twist, conservation's concern with authenticity as 'original condition' now conflicts with a form of authenticity that centres on Hinemihi's place in the community: Ngāti Ranana want to use her as a living whare and add facilities to the existing structure. The National Trust was originally opposed, instead wanting to reinstate the 'original' shingle roof - even though, more 'authentic' at the time, she might have been covered in raupo (bulrush).

28. In the 1980s, the English National Trust approached tribal members to assist with restoration work, which has essentially restored her relationship with her people. A working relationship between hapū and Trust arose, as Hine28. 


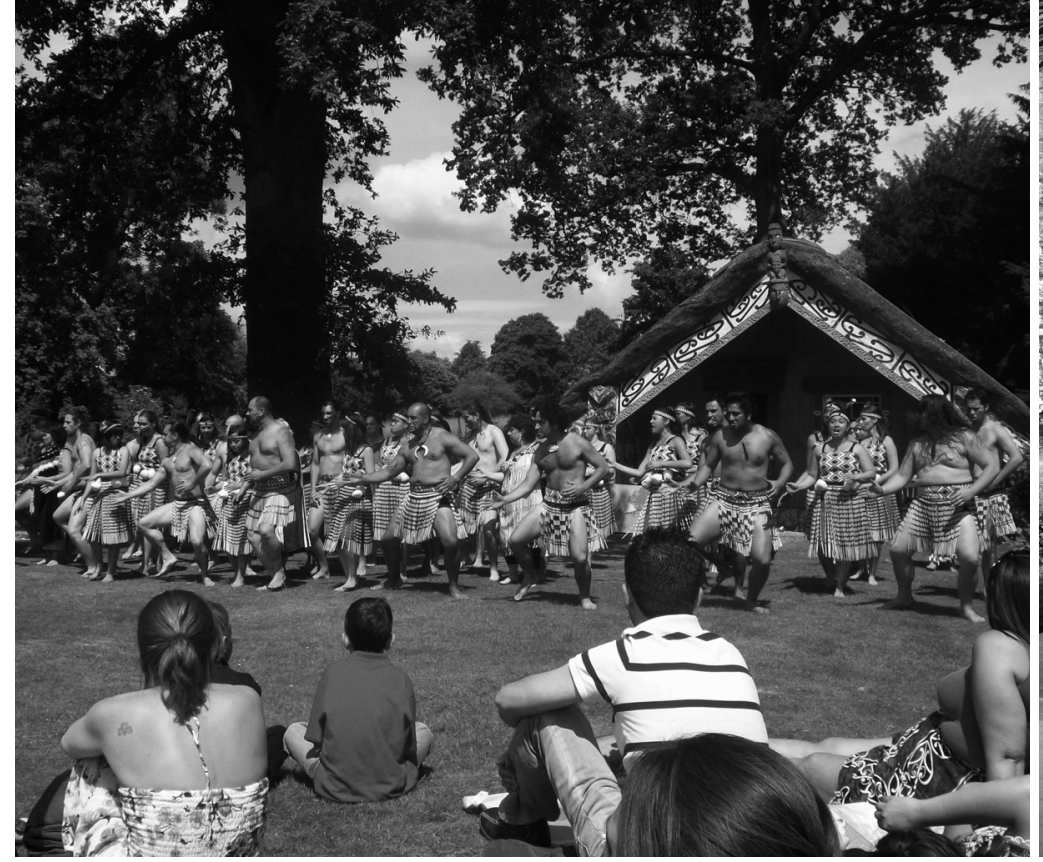

Powhiri at Hinemihi o te Ao Tawhito, Clandon Park, Surrey. Photo: Wikitera 2009

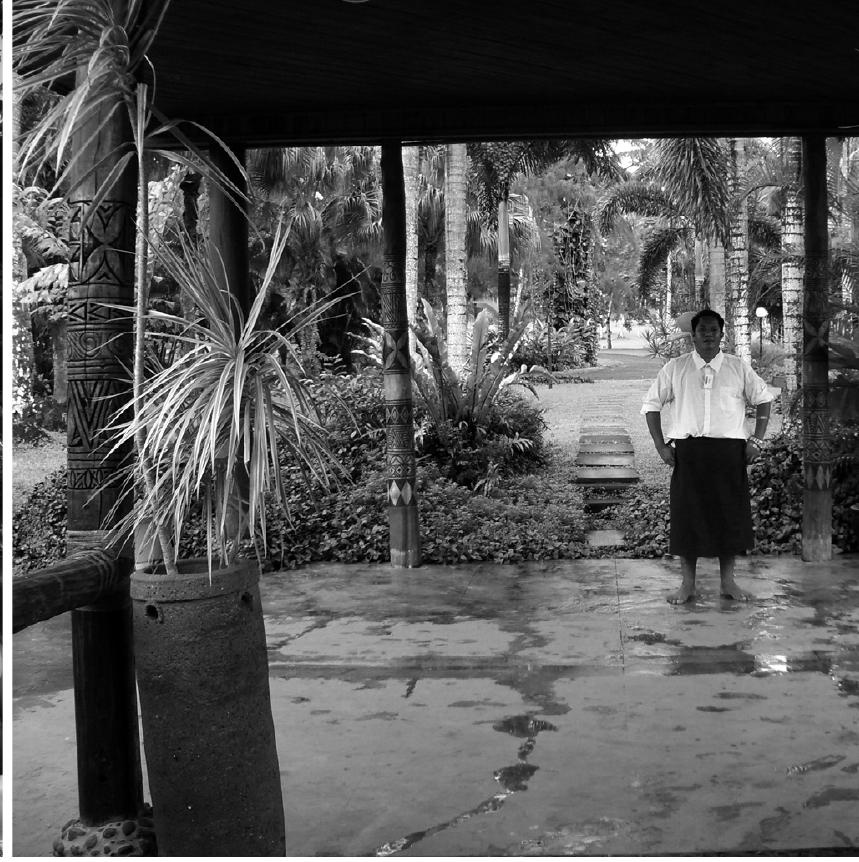

Sinalei Reef Resort \& Spa, entrance area with employee. Photo: Engels-Schwarzpaul 2009
For many and complex reasons, the semiotic production of Adam's House in the Pacific has been ongoing since Europeans displaced the primitive hut's origins into far-away places. It may be increasing under escalating globalisation, which augments fragmentation and differentiation for more and more populations and makes Pasifika peoples ever more dependent on tourism and, with it, staged authenticity. MacCannell mentions an "urgent intimacy, a mutual fragility and co-dependence between icons and social life" (1992: 251), implying that a sustained engagement with the contemporary equivalent of original dwelling in the Pacific is immediately required. Such engagement cannot simply use Paradise as "a screen for our unrealizable dreams and desires, an opportunity for makebelieve, a chance to enter a myth, a fantasy-land" (2008: 337). ${ }^{33}$ It cannot be left to an industry producing ever new versions of saccharine Tropical Islands and Adam's House. Nor can it be an authenticity promoted (and insisted upon) by conservationists. Paradise, as something that never existed but has forever been imagined in endless forms, can be critically engaged and then perhaps become “a promise as well as a memory" (Rykwert 1981: 192).

\section{Samoan Glossary}

\begin{tabular}{ll} 
ava & traditional drink, consumed at ceremonial occasions \\
\hline fa'a Samoa & the Samoan way \\
\hline fale & house \\
fale tele & also, fale fono: guest house, meeting house \\
\hline fono & assembly, council \\
\hline malae & gathering place \\
\hline tala & apse-like round ends on either side of a fale tele \\
\hline tufuga fai-fale & expert, specialist builder
\end{tabular}

33. This engagement must confront the downsides of tourism and iconic architecture in the Pacific: environmental destruction, negative trade balances, and the continued political and economic vulnerability of Pasifika nations vis à vis a growing global expansion of Western trade and investment. See the exhibition Paradise Now? Contemporary Art from the Pacific, whose exhibits critically engaged with "myths of the Pacific as paradise" (Chiu 2004). It must also grapple with similarities and differences between the backgrounds and effects of whare and fale, resulting from an old history and from a recent one, in which Samoa is part of a Third World (independent and according to some in need of development) and Māori in New Zealand belong to a Fourth World (where indigenous people are still under a neo-colonial regime that shapes their sensibilities in different ways). 
Māori Glossary

\begin{tabular}{|c|c|}
\hline hangi & $\begin{array}{l}\text { earth oven, where food is cooked with steam } \\
\text { and heat from stones }\end{array}$ \\
\hline hapū & sub-tribe \\
\hline iwi & tribe \\
\hline kapa haka & concert party, haka group, Māori performance \\
\hline kawa & protocol \\
\hline kohanga reo & language nest, Māori language preschool \\
\hline marae & Māori gathering place \\
\hline powhiri & welcome ceremony \\
\hline tāonga & rized possession, heirloom \\
\hline tapu & sacred, restricted \\
\hline tohunga & expert, specialist \\
\hline tūrangawaewae & place where one has rights of residence \\
\hline whakapapa & genealogy \\
\hline whare nui & $\begin{array}{l}\text { also, whare whakairo, whare puni, whare tūpuna, whare } \\
\text { runanga: meeting house, ancestral house }\end{array}$ \\
\hline
\end{tabular}

\section{References}

Ames, E. (2004). From the Exotic to the Everyday. The ethnographic exhibition in Germany. In J. M. Przyblyski \& V. R. Schwartz (Eds.), Nineteenth Century Visual Culture Reader (pp. 313-327). New York: Routledge.

Armstrong, M. (1992). "A Jumble of Foreignness": The Sublime Musayums of NineteenthCentury Fairs and Expositions. Cultural Critique, 23, 199-250.

Austin, M. (2004). Pacific Island Migration. In S. Cairns (Ed.), Drifting: Architecture and Migrancy (pp. 224-238). London: Routledge.

Benedict, B. (1991). International Exhibitions and National Identity. Anthropology Today, 7(3), 5-9.

Buck, T. R. H. (1949). Samoan Material Culture. Honolulu: Bernice P. Bishop Museum.

Butt, D. J. (2003). Māori and Museums. The Politics of Indigenous Recognition. Massey University, Palmerston North.

Chiu, M. (2004). Paradise now? Contemporary Art from the Pacific. Retrieved 7 June, 2008, from http://www.asianart.com/exhibitions/paradise/essay.html

Culin, S. (1894). Retrospect of the Folk-Lore of the Columbian Exposition. The Journal of American Folklore, 7(24), 51-59.

dpa. (2004). World's largest indoor rainforest gets the nod. Retrieved 3 March, 2006, from http://www.skyscrapercity.com/showthread.php?t=88305

Durie, M. (2008, 23 January 2008). 2008 Manu-Ao Lecture: The Determinants of Transformation. Paper presented at the Nga Pae o te Maramatanga Writing Retreat, Hopuhopu, Massey University. http://tur-media-db1.massey.ac.nz/mediasite/Viewer/?peid=a87bbc784e62-491d-9e33-741af8583f41

Engels-Schwarzpaul, A.-Chr. (2007). "A warm grey fabric lined on the inside with the most lustrous and colourful of silks": Dreams of airships and tropical islands. The Journal of Architecture, 12(5), 525-542. 
Engels-Schwarzpaul, A.-Chr., \& Refiti, A. L. (2006-2009). Tropical Islands - Virtual Worlds. Unpublished Interviews With Research Participants. AUT University, Auckland.

Finley, J. P., \& Churchill, W. (1923). The Subanu; studies of a sub-Visayan mountain folk of Mindanao. Retrieved 14 May 2009, from http://www.archive.org/details/subanustudiesofs00finl

Furnas, J. C. (1948). Anatomy of Paradise: Hawaii and the Islands of the South Seas. Retrieved 12 June 2009, from http://www.archive.org/stream/anatomyofparadis012497mbp/anatomyofparadis012497mbp_djvu.txt

Gallop, A. (1998). The House with The Golden Eyes. London: Running Horse Books Limited.

Herdrich, D. J. (2000). Exhibitions Featuring Samoans. Retrieved 10 March, 2009, from http:// www.samoa.co.uk/old-exhibitions.html

Houkamau, C. A. (2006). Identity and Socio-Historical Context: Transformations and Change Among Maori Women. University of Auckland, Auckland. http://researchspace.auckland. ac.nz/handle/2292/404

Johnston, E. C. (1999). Representing the Pacific at international exhibitions 1851-1940. Unpublished PhD Thesis, University of Auckland, Auckland.

Kleist, H. v. (1982). An Abyss Deep Enough. Letters of Heinrich von Kleist with a Selection of Essays and Anecdotes (edited by Philip B. Miller). New York: E. P. Dutton.

Krämer, A. (1994). The Samoa Islands (Vol. 2 - Material Culture). Honolulu: University of Hawaii Press.

MacCannell, D. (1990). Cannibal Tours. Society For Visual Anthropology Review, 6(2), 14-24.

MacCannell, D. (1992). Empty meeting grounds: The tourist papers. London: Routledge.

MacCannell, D. (2008). Why it Never Really was About Authenticity. Society, 45(4), 334-337.

Neich, R. (1990-1991). The Maori carving art of Tene Waitere: traditionalist and innovator. Art New Zealand, 57(Summer), 73-79.

Polynesian Cultural Center. (n.d.-a). Aotearoa (New Zealand): The Pa or Village. Retrieved 12 December, 2008, from http://www.polynesia.com/new-zealand/the-pa-or-village.html

Polynesian Cultural Center. (n.d.-b). Early History I Polynesian Cultural Center. Retrieved 12 June, 2007, from http://www.polynesia.com/early-history.html

Polynesian Cultural Center. (n.d.-c). Rainbows of Paradise. Retrieved 16 June, 2009, from http://polynesia.com/shows/rainbows-of-paradise.html

Preziosi, D. (1982). Constru(ct)ing the Origins of Art. Art Journal, 42(4) - The Crisis in the Discipline), 320-325.

Refiti, A. L. (2008). Whiteness, Smoothing and the Origin of Samoan Architecture. Paper presented at the On Adam's House in the Pacific. Symposium in Honour of Joseph Rykwert, Auckland: University of Auckland. http://library.creative.auckland.ac.nz/common/ library/2008/11/architecture/adamshouse.pdf

Rydell, R. (1978). The World's Columbian Exposition of 1893. Journal of American Culture, 1(2), 253-275.

Rykwert, J. (1981). On Adam's House in Paradise. The Idea of the Primitive Hut in Architectural History. Cambridge: The MIT Press.

Rykwert, J. (1982). Semper and the Conception of Style. In The necessity of artifice: ideas in architecture (pp. 123-140). London: Academy Editions.

Salesa, D. (2005). Misimoa: An American on the Beach. Common-place: The Interactive Journal of Early American Life, 5(2 Special Issue: Pacific Routes). Retrieved from http://www. historycooperative.org/journals/cp/vol-05/no-02/salesa/index.shtml

Semper, G. (1878). Der Stil in den technischen und tektonischen Künsten, oder Praktische Aesthetik. Ein Handbuch für Techniker, Künstler und Kunstfreunde. Erster Band. Textile Kunst. München: Friedrich Bruckmann's Verlag.

Sinalei Reef Resort \& Spa. (2008). Guest information brochure (available in the room on 8.2.2009). Apia, Samoa: Sinalei Reef Resort \& Spa. 
Sinalei Reef Resort \& Spa. (n.d.-a). About Sinalei. Retrieved 13 March, 2009, from http:// www.sinalei.ws/Sinalei/about.aspx

Sinalei Reef Resort \& Spa. (n.d.-b). Simply Sinalei (promotional card received 8.2.2009). Apia, Samoa.

Sinalei Reef Resort \& Spa. (n.d.-c). Take me away ... [Promotional Brochure] (pp. 8). Apia, Samoa: Sinalei Reef Resort \& Spa.

Sissons, J. (1998). The traditionalisation of the Maori meeting house. Oceania, 69(1), 36.

Skinner, D. (2008). The Carver and the Artist: Maori Art in the Twentieth Century. Auckland: Auckland University Press.

Smith, L. T. (1999). Decolonizing Methodologies. Research and Indigenous Peoples. Dunedin: University of Otago Press.

Stillman , A. K. 1. (2004). Pacific-ing Asian Pacific American History. Journal of Asian American Studies, 7(3), 241-270.

Suaalii-Sauni, T., Tuagalu, I., Kirifi-Alai, T. N., \& Fuamatu, N. (Eds.). (2008). Su'esu'e Manogi - In Search of Fragrance: Tui Atua Tupua Tamasese Ta'isi and the Samon Indigenous reference. Apia: The Centre for Samoan Studies.

Tcherkézoff, S. (2008). Culture, nation, society. In T. Serge \& D.-M. Françoise (Eds.), The Changing South Pacific. Identities and Transformations (pp. 245-301). Canberra: ANU Press.

Terrell, J. E., Wisse, D. C. J., \& Philipp, C. J. (2007). Ruatepupuke II, The Field Museum, Chicago: The Past and Possible Futures. In D. Sully (Ed.), Decolonising Conservation: Caring for Maori Meeting Houses Outside New Zealand (pp. 89-109). Walnut Creek, CA: Left Coast Press.

Thomas, N. (2009). Tene Waitere: Māori Carving and Colonial History. Dunedin: Otago University Press.

Tropical Island Management GmbH. (2008). Tropical Islands. Discover Europe's Largest Tropical Holiday World. Retrieved 6 May, 2009, from http://www.tropical-islands.de/en/ visitors.html

Tropical Island Management GmbH. (2005). Samoa Fale. Open Houses for living in the South Seas. Retrieved 12 November, 2005, from http://www.my-tropical-islands.com/village/ samoa-fale-e.htm

Tui Atua. (2008). Resident, Residence, Residency in Samoan Custom. In T. i. Suaalii-Sauni, I. u. Tuagalu, T. N. Kirifi-Alai \& N. Fuamatu (Eds.), Su'esu'e Manogi - In Search of Fragrance: Tui Atua Tupua Tamasese Ta'isi and the Samon Indigenous reference (pp. 93-103). Apia: The Centre for Samoan Studies.

Wai 46. A Claim by Hirini Moko Mead and others for Ngāti Awa relating to Ngāti Awa. (1994). Retrieved 12 January 2009, from http://www.waitangi-tribunal.govt.nz/reports/viewchapter.asp?reportID=a949cd08-4825-48bf-b038-fac923793297\&chapter=13\#32932

Webb, T. D. (1998). A New Kind of Plantation. The Polynesian Cultural Center in Lāie, Hawai i. $C R M(8), 33-36$.

Wesley, R. (1998). The Idea of a House. Res, 34(Autumn), 119-128. 